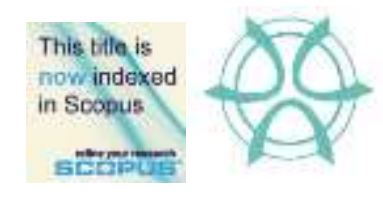

PLANNING MALAYSIA:

Journal of the Malaysian Institute of Planners

Volume XIII (2015), Page 1 - 18

\title{
CREATIVE CITIES RESEARCH IN PENANG, MALAYSIA: A REVIEW OF CONCEPTUAL AND METHODOLOGICAL FRAMEWORK
}

\author{
Khoo Suet Leng ${ }^{1}$, Nurwati Badarulzaman ${ }^{2}$, Narimah Samat ${ }^{3}$, Morshidi Sirat ${ }^{4} \&$ \\ Sharifah Rohayah Sheikh Dawood ${ }^{5}$ \\ ${ }^{1}$ Department of Development Planning and Management \\ ${ }^{2}$ Department of Urban and Regional Planning \\ ${ }^{3,4 \& 5}$ Department of Geography \\ UNIVERSITI SAINS MALAYSIA
}

\begin{abstract}
A heightened interest in the notions of 'creative cities, creative industries and creative economy' has propelled research in these emerging areas of the New Economy. As an emerging area, some conceptual and methodological issues need to be addressed prior to adopting the creative city paradigm as part of the strategic and policy framework towards a creative economy. This paper presents a review of key conceptual and methodological issues that need to be considered when conducting research on creative cities in Malaysia. The conceptual and methodological issues relating to creative cities and creative industries should be addressed and dealt with in order to facilitate an enabling framework for contemporary research in this emerging area.
\end{abstract}

Keyword: Creative cities, creative industries, creative economy 
Khoo Suet Leng, Nurwati Badarulzaman, Narimah Samat, Morshidi Sirat \& Sharifah Rohayah Sheikh Dawood Creative Cities Research In Penang, Malaysia: A Review Of Conceptual And Methodological Framework

\section{INTRODUCTION}

The discourse on creative cities is gaining much importance and increasingly pivotal in contemporary academic and political agenda. The discourse deliberates on the intrinsic link between creativity and urban development, and the contribution of creative activities towards territorial development and competitiveness (Costa, 2008). Creative cities are purported as the model cities of the 21 st century, where cities of this nature would grow, thrive and progress as a result of an agglomeration of creative industries, which feature a clustering force of their skilled, innovative and creative urbane workforce (Florida, 2008, 2004, 2002; Lazzeretti, Boix \& Capone, 2009; Cooke \& Lazzeretti, 2008). The presence of such creative workers or popularly known as the 'creative class' (Florida, 2002), will be the key determinant towards a city's liveability, attractiveness and future economic progress. Consequently, cities around the world strive to compete to be the location of choice in their quest to attract and retain the creative class.

Arguably, in the New Economy it is cities rather than countries or nations that compete against each other for economic dominance and wealth. In essence, a city needs to transform itself into a creative city in order to contest effectively since "...the concept of creative city can be seen as the newest place-marketing product, employed in the struggle between cities to attract investors and to promote competitiveness" (Hansel et al., 2001, cited in Costa, 2008). Statistics from advanced economies such as the United Kingdom, Canada and Singapore highlight the significance of creative industries clustering in cities and their contributions towards local and national development (DCMS, 2010; Cooke \& Lazzeretti, 2008; AuthentiCity, 2008; Toh, Choo \& Ho, 2003). Hence, many developing countries including Malaysia share the same aspiration to transform their primary or secondary cities to become creative cities (Lee, 2011; Khoo \& Nurwati, 2011). Specifically, Malaysia's National Creative Industry Policy aims to strengthen the local creative industries and leverage on the creative economy bandwagon to spur economic progress.

However, critiques have underlined some key issues regarding the conceptual and methodological comprehension of the notions of 'creative cities/creative industries/creative economies' and their usability. The current scenario depicts a "...rather confusing and unclear panorama around the corelated creative cities and creative/cultural activities concepts" (Costa, 2008: 188). Furthermore, "creative city notion has been particularly in the spotlight in the past decade, but it is not easy to identify a common conceptual ground covering the underlying diversity of interpretations and practices" (Costa, 2008: 191). Given the blurry boundaries between the notions of 'creative activities' and 'cultural activities', arguably, these conceptual issues are specific and peculiar to creative industries and the notion of 'creativity' per se. 
PLANNING MALAYSIA

Journal of the Malaysia Institute of Planners (2015)

Apart from the conceptual predicaments, a lack of understanding of the tangible dimensions and parameters of targeted economic performance poses another challenge to current research on creative cities and creative industries. The strength of a city's creative economy is usually measured in terms of the number of creative businesses, total number of creative employees, and total wealth generated by the creative employees (CIE, 2009; Montgomery, 2005). Admittedly, creative inputs that can boost tangible economic outcomes provide vital statistics to operationalise and assess the "economic dimensions of creative industries as a driver of wealth creation, employment, competitiveness and prosperity" (CIE, 2009: 9). To date, however, most countries have yet to publish the tangible economic dimensions and quantifiable objective indicators that are related to their creative cities and creative industries (Costa, 2009). Data on Malaysia's creative industries based on selected economic indicators (or proxies) is unavailable. This situation poses a real challenge given the dearth of creative cities research in Malaysia.

Against this background, this paper aims to fill the above research gap by reviewing the conceptual and methodological issues and challenges in creative cities and creative industries research. Essentially, the main objective of this paper is to disclose and unpack key conceptual issues and also latent methodological challenges that are hindering and obstructing research and practical developments in the field of creative cities and creative economies in Malaysia. Though several diverse and contentious concepts were highlighted, the convergent meaning found in the conceptual and methodological review adds on to the rigour and internal consistency of the working framework for this study. Issues and challenges discussed in this paper would provide some baseline data for future research on creative cities, creative industries and economic development especially in Malaysia. In addition, the Malaysian authorities and related statutory bodies may devise an appropriate taxonomy to document the contribution and development of creative industries as the city's latest engine of growth in the New Economy.

\section{REVIEW OF CONCEPTUAL FRAMEWORK}

Creative industries have multiple definitions and meanings; and the debate continues on the inherent linkages that exist between creative industries and cultural industries (Costa, 2008). The literature highlights two distinct approaches in explaining the complex connections between creative industries and cultural industries. The first approach hinges on the dimension of culture and its supplementary contributions in the elements of politics, economics and environment in order to provide a holistic and sustainable condition for the birth of a creative city (Kern \& Runge, n.d.; Landry, 2000). As the forces of economic globalisation set in, advanced economies rapidly lose their manufacturing base and they progress into their next development phase with the birth of a new 
Khoo Suet Leng, Nurwati Badarulzaman, Narimah Samat, Morshidi Sirat \& Sharifah Rohayah Sheikh Dawood Creative Cities Research In Penang, Malaysia: A Review Of Conceptual And Methodological Framework

knowledge and informational economy. Artistic and technological creativity become the prime driver of the new knowledge economy, thus, placing creativity as a focal point of urban development policy (Sasaki, 2008). Interestingly, the link between culture and the arts is not novel; and can be traced back to the pioneers of cultural economists like John Ruskin and William Morris, who during England's Victorian period championed the art economics that capitalise on creative human activities (Sasaki, 2008). A similar line of inquiry was later pursued by Lewis Mumford in Culture of Cities where he proposed cultural economics, which emphasises human life and environment over everything else, thus, placing much focus on "reconstitution of cities to fulfil human consumption and creative activities" (Mumford, 1938, cited in Sasaki, 2008: 78).

The second approach, on the other hand, hinges on economics and development. The concept of creative cities has evolved to encapsulate the dimensions of creativity and innovation of a city, as pioneered in Jane Jacobs' work (1972). Extending from Jacobs' work are proponents like Florida (2008, 2004, 2002) and Landry (2000) who define creativity as something beyond fantasy and imagination. They place creativity somewhere between intelligence and innovation, so that the concept acts as a "mediator" between art and culture and between industry and technology (Sasaki, 2008). A creative economy comprises creative industries fuelled by creative and innovative individuals (or creative class) who choose to congregate and agglomerate with other creative workers in urban areas in order to spur local economic development (Florida, 2008, 2006, 2002).

It is clear that the first approach leverages on elements that are linked to arts and culture; whilst the second approach is inclined towards capitalising creativity and innovation for economic development. These two differing conceptual definitions of the creative city as 'culture-centric' as opposed to 'econo-centric' orientations are compared and contrasted in Table 1. The contrasting orientation is posited by Smith and Warfield (2008: 288) as follows:

"According to what we call the culture-centric conception of the creative city, value
is placed foremost on creative acts, which benefit the well-being and quality of life
of citizens; the economic benefit and value is secondary. What we have termed the
economic-centric orientation, on the other hand, sees local economic development
and growth as primarily important, and artistic values are secondary".

Table 1: Creative city orientations - 'Culture-centric' versus 'Econo-centric'

\begin{tabular}{lll}
\hline \multicolumn{1}{c}{$\begin{array}{c}\text { Creative City } \\
\text { Orientations }\end{array}$} & \multicolumn{1}{c}{ Culture-Centric } & \multicolumn{1}{c}{ Econo-Centric } \\
\hline Creative city values & $\begin{array}{l}\text { Central values = arts, culture, } \\
\text { community well-being, access } \\
\text { and inclusion }\end{array}$ & $\begin{array}{l}\text { Central values = urban economic } \\
\text { sustainability and well-being through } \\
\text { creative initiatives/industries }\end{array}$ \\
\hline Definition of creative city & $\begin{array}{l}\text { Place of diverse and inclusive arts } \\
\text { and culture }\end{array}$ & $\begin{array}{l}\text { Place of economic innovation, } \\
\text { creative talent and creative industries }\end{array}$ \\
\hline
\end{tabular}

Source: Smith and Warfield (2008: 289) 
PLANNING MALAYSIA

Journal of the Malaysia Institute of Planners (2015)

Such delineated approaches of the "art-culture-creative-knowledge continuum" versus "cross-cultural interpretations" have caused major semantics and epistemology issues in this field (Mossberger and Stoker, 2001, cited in Evans, 2009). For instance, nebulous definition was an issue in assessing the creative industries in Liverpool (Liverpool City Council, 2009). Moreover, in articulating and validating the meta-themes on global culture and creative industries, tensions have emerged between city-regional authorities who champion creative and knowledge city status via economic-led cultural policy, against those local authorities and municipalities who are ingrained with cultural development and objectives for their arts and cultural policy and programmes (Evans, 2009). This dilemma has caused some Midwest American cities to define their creative economy in terms of cultural heritage, rather than creative class (Evans, 2009).

It is hardly surprising that some industries and occupations in the creative industries and cultural industries classifications are in fact overlapping. In Europe, there are efforts to consider indicators related to culture-based creativity to be incorporated into existing socio-economic indicators (Kern \& Runge, n.d.). The Europeans have developed the term "culture-based creativity" to reflect 'art and cultural production or activities which nurture innovation' (Kern \& Runge, n.d., p. 192) as follows:

\footnotetext{
Culture-based creativity is linked to the ability of people, notably artists, to think imaginatively or metaphorically, to challenge the conventional, and to call on the symbolic and effective to communicate. Culture-based creativity is a capacity to break the natural order, the usual way of thinking and to allow the development of a new vision, an idea or a product. Culture-based creativity is creativity that comes from artists, creative professionals and the cultural and creative industries.
}

It is generally agreed that creative industries are those that derive value from copyright and circulating creative content, whilst cultural industries produce creative content in a local cultural setting through literary, visual and performing arts (Evans, 2009). A widely accepted definition is that of the Creative Industries Task Force (CITF, 1998) of the United Kingdom, which defines creative industries as "activities which originated in individual creativity, skill and talent and which have the potential for wealth and job creation through the generation and exploitation of intellectual property."

A later document entitled 2001 Creative Industries Mapping Document follows this definition and identifies 13 industries of specific classifications as creative industries. These industries are (1) advertising; (2) architecture; (3) art and antiques; (4) crafts; (5) design; (6) designer fashion; (7) film and video; (8) interactive leisure software; (9) music; 10) the performing arts; 11) publishing; 12) software and computer services; and 13) television and radio. Table 2 illustrates the attempt by the British government to map out the 13 creative 
Khoo Suet Leng, Nurwati Badarulzaman, Narimah Samat, Morshidi Sirat \& Sharifah Rohayah Sheikh Dawood Creative Cities Research In Penang, Malaysia: A Review Of Conceptual And Methodological Framework

industries to the 2007 Standard Industrial Classification (SIC) for Annual Business Survey (ABS) data.

Table 2: Mapping of UK's Creative Industries to the 2007 Standard Industrial Classification (SIC) for Annual Business Survey (ABS) data

\begin{tabular}{|c|c|c|c|}
\hline \multirow{2}{*}{$\begin{array}{l}\text { Mapping } \\
\text { Document } \\
\text { Chapter }\end{array}$} & \multirow[t]{2}{*}{ Sector } & \multicolumn{2}{|r|}{ Standard Industrial Classification (SIC) } \\
\hline & & Code & Description \\
\hline \multirow[t]{2}{*}{1} & Advertising & 73.11 & Advertising agencies \\
\hline & & 73.12 & Media representation \\
\hline \multirow[t]{2}{*}{2} & Architecture & 71.11 & Architectural activities \\
\hline & & 74.10 & Specialised design activities \\
\hline \multirow[t]{2}{*}{3} & Art \& Antiques & $47.78 / 1$ & Retail sale in commercial art galleries \\
\hline & & $47.79 / 1$ & $\begin{array}{l}\text { Retail sale of antiques including antique books, in } \\
\text { stores }\end{array}$ \\
\hline 4 & Crafts & \multicolumn{2}{|c|}{ Majority of businesses too small to be picked up in business surveys. } \\
\hline 5 & Design & 74.10 & Specialised design activities \\
\hline \multirow[t]{2}{*}{6} & Designer Fashion & 10 Codes & Clothing Manufacture \\
\hline & & 74.10 & Specialised design activities \\
\hline \multirow[t]{6}{*}{7} & $\begin{array}{l}\text { Video, Film \& } \\
\text { Photography }\end{array}$ & $18.20 / 2$ & Reproduction of video recording \\
\hline & & 74.20 & Photographic activities \\
\hline & & $\begin{array}{l}59.11 / 1 \& \\
59.11 / 2\end{array}$ & Motion picture and video production activities \\
\hline & & 59.12 & $\begin{array}{l}\text { Motion picture, video \& TV post-production } \\
\text { activities }\end{array}$ \\
\hline & & $\begin{array}{c}59.13 / 1 \& \\
59.13 / 2\end{array}$ & Motion picture and video distribution activities \\
\hline & & 59.14 & Motion picture projection activities \\
\hline \multirow[t]{7}{*}{$9 \& 10$} & $\begin{array}{l}\text { Music, Visual \& } \\
\text { Performing Arts }\end{array}$ & 59.20 & Sound recording and music publishing activities \\
\hline & & $18.20 / 1$ & Reproduction of sound recording \\
\hline & & 90.01 & Performing arts \\
\hline & & 90.02 & Support activities to performing arts \\
\hline & & 90.03 & Artistic creation \\
\hline & & 90.04 & Operation of arts facilities \\
\hline & & $78.10 / 1$ & $\begin{array}{l}\text { Motion picture, television and other theatrical } \\
\text { casting }\end{array}$ \\
\hline \multirow[t]{5}{*}{11} & Publishing & 58.11 & Book publishing \\
\hline & & 58.13 & Publishing of newspapers \\
\hline & & 58.14 & Publishing of journals and periodicals \\
\hline & & 58.19 & Other publishing activities \\
\hline & & 63.91 & News agency activities \\
\hline \multirow[t]{4}{*}{$8 \& 12$} & $\begin{array}{l}\text { Software \& } \\
\text { Electronic } \\
\text { Publishing }\end{array}$ & $18.20 / 3$ & Reproduction of computer media \\
\hline & & $62.01 / 2$ & Business and domestic software development \\
\hline & & 62.02 & Computer consultancy activities \\
\hline & & 58.29 & Other software publishing \\
\hline \multirow[t]{2}{*}{$8 \& 12$} & $\begin{array}{l}\text { Digital \& } \\
\text { Entertainment } \\
\text { Media }\end{array}$ & 58.21 & Publishing of computer games \\
\hline & & $62.01 / 1$ & $\begin{array}{l}\text { Ready-made interactive leisure and entertainment } \\
\text { software development }\end{array}$ \\
\hline
\end{tabular}


PLANNING MALAYSIA

Journal of the Malaysia Institute of Planners (2015)

\begin{tabular}{|l|l|c|l|}
\hline 13 & Radio \& TV & 60.10 & Radio broadcasting \\
\hline & & 60.20 & Television programming and broadcasting activities \\
\hline & $59.11 / 3$ & TV programmes production activities \\
\hline & 59.12 & $\begin{array}{l}\text { Motion picture, video \& TV post-production } \\
\text { activities }\end{array}$ \\
\hline & & $59.13 / 3$ & TV programme distribution activities \\
\hline
\end{tabular}

This original concept of creative industries has inevitably evolved and assimilated into different contexts. For instance, creative industries in Toronto, Canada are defined by industries and occupations as shown in Table 3. An Australian study mirrors this taxonomy in their cultural and creative industries in line with the UNESCO definition: "...the cultural and creative industries focused on both activities involved in the creation of cultural and creative goods and services as well as activities that subsequently add value to those products" (CIE, 2009: 18). The creative industries in the Australian study comprise (i) music and performing arts; (ii) film, television and radio; (iii) advertising and marketing; (iv) software development and interactive content; (v) writing, publishing and print media; and (vi) architecture, design and visual arts (CIE, 2009).

Table 3: Definition of creative industries in the city of Toronto, Canada (by industries and by occupations)

\begin{tabular}{|c|c|}
\hline Creative Industries & Creative Occupations \\
\hline $\begin{array}{l}\text { - } \text { Independent Artists, Writers and Performers } \\
\text { - } \quad \text { Performing Arts Companies } \\
\text { - } \text { Agents and Promoters of Performing Arts and } \\
\text { Entertainers } \\
\text { - } \quad \text { Motion Picture and Video Production } \\
\text { - } \quad \text { Radio and TV Broadcasting, Pay/Specialty TV, } \\
\text { - } \quad \text { And Program Distribution } \\
\text { - } \text { Specialised Design Services (Graphic, } \\
\text { - } \quad \text { Advecture and Related Services } \\
\text { - } \quad \text { Newspaper, Periodical, Book and Database } \\
\text { - } \quad \text { Publishing } \\
\text { Software and New Media Publishing }\end{array}$ & $\begin{array}{ll}\text { - } & \text { Architects \& Landscape Architects } \\
\text { - } & \text { Industrial, Graphic \& Interior Designers } \\
\text { - } & \text { Writers \& Editors } \\
\text { - } & \text { Producers, Directors, Choreographers \& } \\
\text { - } & \text { Related Occupations } \\
\text { - } & \text { Musicians, Singers \& Dancers } \\
\text { - } & \text { Actors and Others Performers } \\
\text { - } & \text { Painters, Sculptors, Illustrating Artists \& } \\
\text { - } & \text { Other Visual Artists } \\
\text { - } & \text { Annotographers } \\
\text { - } & \text { Theatre, Fashion, Exhibit \& Other Creative } \\
& \text { Designers } \\
\text { - } & \text { Artisans, Craftspersons and Patternmakers }\end{array}$ \\
\hline
\end{tabular}

\section{ECONOMIC MEASURES OF CREATIVE INDUSTRIES}

The economic dimensions or parameters of the creative industries are key determinants to ascertain whether a city qualifies to be branded as a creative city. The number of current creative businesses and creative employees as well as the amount of wealth they create are vital statistics and indicators to assess and position the importance of creative industries in a particular city or nation (Montgomery 2005). Advanced economies such as the UK, Australia and Singapore have embarked on this endeavour to document and measure the 
Khoo Suet Leng, Nurwati Badarulzaman, Narimah Samat, Morshidi Sirat \& Sharifah Rohayah Sheikh Dawood Creative Cities Research In Penang, Malaysia: A Review Of Conceptual And Methodological Framework

importance of the creative industries in their respective economies. The British Government through the Department for Culture, Media and Sport (DCMS, 2010) has compiled these dimensions in a report entitled Creative Industries Economic Estimates released in December 2010, which reported that seven creative industries comprised 5.6\% of the UK's Gross Value Added in 2008. On employment, the total creative employment contributes $7.8 \%$ as a proportion of all employment totalling to 2,278,500 jobs in November 2010 (DCMS, 2010).

Likewise in Australia, documenting the economic dimensions was undertaken by the Centre for International Economics (Canberra \& Sydney) in a report entitled Creative Industries Economic Analysis (2009). The comprehensive Australian effort to capture and measure creative industries statistics based on time series and longitudinal approach is commendable. Multiple sources including the IBIS World Industry reports and ABS Census were consulted to construct the array of economics dimensions for the Australian creative industries. It was reported that the average contribution of the Australian creative industries to Gross Domestic Product (GDP) from 2004-05 to 2007-08 was about 2.8 per cent (CIE, 2009).

Malaysia's southern neighbour, Singapore, is also rapidly transforming itself into a creative city (Hing, 2008). Singapore is harnessing its creative industries as a primary engine of growth in the new knowledge-based economy. This national aspiration is documented in a blueprint entitled Economic Contributions of Singapore's Creative Industries which highlights how "the creative industries leverage on multi-dimensional creativity of individuals to create new economic values" (Toh, Choo \& Ho, 2003: 51). In 2000, Singapore's Department of Statistics reported that the value of creative industries was around $3 \%$ of GDP. Singapore aims to develop the nation's creative industries to contribute 6\% of GDP by 2012 and to employ 5-7\% of the national workforce. These figures are comparable to other established creative cities such as London, New York, San Francisco and Venice. It is clear that the economic dimensions of the creative industries are vital determinants to indicate the strength of creative industries in a nation or a city, failing which would undermine the city's capacity to transform into a creative economy.

\section{METHODOLOGY}

Literature on creative industries and creative cities is mainly inclined towards the advanced economies; but research of this nature is scarce in the Malaysian context. As Malaysia's economy embarks on a structural transformation towards services, this study on creative industries (which is predominantly service-based industries) is most timely. The inception of the National Creative Industries Policy in 2009 saw funds allocated to spur Malaysian creative industries such as film, music, animation, software development and other related creative 
activities. The availability of key statistics and data to illustrate the importance of these industries are, therefore, vital.

This study heeds this national call. Funded by the Universiti Sains Malaysia's Research University Grant, this study aims to explore the contribution of creative industries to economic growth in Malaysia. The following section explains the methodological challenges encountered in this pioneering study of creative industries in Malaysia.

\section{Data Availability}

Despite the existence of diverse taxonomy and classification of creative industries as reviewed earlier, this research opted for the classification used by the UK's DCMS (2010). Based on the United Kingdom DCMS's 13-sector classification, this study focused on obtaining secondary data on Malaysia's creative industries from existing Government blueprints such as the Five-Year Malaysia Plans, Malaysian Economic Reports and such. However, the attempt was futile since all these reports adopted the conventional method of displaying data and statistics. To date, all industries and sectors in the Malaysian economy are presented based on the Clark-Fisher's three sector model, namely, i) agriculture (First Sector); ii) industrial (Second Sector); and iii) services (Third Sector). No attempt has been made as yet to document and illustrate the contribution of Malaysia's creative industries to the economy.

The study then opted to source for primary data by contacting Malaysia's Department of Statistics (DOS). Correspondence between the researcher and DOS revealed another stumbling block. Apparently, Malaysia's existing classification does not support the creative industries classification as proposed in this study. DOS suggested the possibility to overlay and match UK's 13-sector of creative industries to the existing classification (i.e. Malaysia Standard Industrial Classification 2008, Version 1.0), which is currently used by DOS.

\section{Malaysia Standard Industrial Classification 2008 (MSIC) Ver. 1.0}

The Malaysia Standard Industrial Classification 2008 (MSIC) Ver. 1.0 is a classification of all economic activities in Malaysia. It adopts the International Standard Industrial Classification (ISIC) Revision 4 that was released in December 2006, incorporating all the necessary modifications to meet national requirements (MSIC, 2008). The main objective of the MSIC is to provide a set of activity categories that can be utilised for the collection and illustration of statistics according to such activities; of which industries are then established by grouping units with a common primary activity, based on specified similarity criteria (MSIC, 2008). The structure provided by MSIC 2008 Ver. 1.0 is based on a 'hierarchical levels of activities.' The highest aggregation level known as "section" has 21 tabulation categories, and each is denoted by a single alphabetical letter as shown in Table 4. 
Khoo Suet Leng, Nurwati Badarulzaman, Narimah Samat, Morshidi Sirat \& Sharifah Rohayah Sheikh Dawood Creative Cities Research In Penang, Malaysia: A Review Of Conceptual And Methodological Framework

Table 4: Hierarchical levels of activities based on Malaysia's MSIC 2008 Ver. 1.0

\begin{tabular}{clc}
\hline Sections & Description & Divisions \\
\hline A & Agriculture, forestry and fishing & $01-03$ \\
B & Mining and quarrying & $05-09$ \\
C & Manufacturing & $10-33$ \\
D & Electricity, gas, steam and air conditioning supply & 35 \\
E & Water supply; sewerage, waste management and remediation & $36-39$ \\
& activities & $41-43$ \\
F & Construction & $45-47$ \\
G & Wholesale and retail trade; repair of motor vehicles and motorcycles & $49-53$ \\
H & Transportation and storage & $55-56$ \\
I & Accommodation and food service activities & $58-63$ \\
J & Information and communication & $64-66$ \\
K & Financial and insurance/takaful activities & 68 \\
L & Real estate activities & $69-75$ \\
M & Professional, scientific and technical activities & $77-82$ \\
N & Administrative and support service activities & 84 \\
O & Public administration and defence; compulsory social security & 85 \\
P & Education & $86-88$ \\
Q & Human health and social work activities & $90-93$ \\
R & Arts, entertainment and recreation & $94-96$ \\
S & Other service activities & $97-98$ \\
T & Activities of households as employers; undifferentiated goods- and & 99 \\
U & services-producing activities of households for own use &
\end{tabular}

In MSIC, there are 88 two-digit divisions which constitute the highest numerical category. They are further broken down into more detailed categories encompassing 238 three-digit groups and 423 four-digit classes. In total, there are 1,197 five-digit items at the most detailed level. For instance, the formation of the five-digit code for items in Section A - 'Agriculture, forestry and fishing' is shown in Table 5. The summary of detailed levels used in MSIC is shown in Table 6.

Table 5: Example of formation of the five-digit code for each item

\begin{tabular}{clc}
\hline Section A - 'Agriculture, forestry and fishing' is illustrated below: & Codes \\
\hline Level & Title and Description & A \\
\hline Section & Agriculture, Forestry and Fishing & 01 \\
Division & Crop and animal production, hunting and related service & \\
& activities & 011 \\
Group & Growing of non-perennial crops & 0111 \\
Class & Growing of cereals (except paddy), leguminous crops and oil & 01111 \\
& seeds & 01112 \\
& Growing of maize & 01113 \\
& Growing of leguminous crops & 01114 \\
\hline
\end{tabular}

(Source: MSIC 2006, p.5) 
PLANNING MALAYSIA

Journal of the Malaysia Institute of Planners (2015)

Table 6: Summary of detailed levels used in MSIC.

\begin{tabular}{ccccc}
\hline Sections & Divisions & Groups & Classes & Items \\
\hline A & 3 & 13 & 38 & 142 \\
B & 5 & 10 & 14 & 56 \\
C & 24 & 71 & 137 & 259 \\
D & 1 & 3 & 3 & 8 \\
E & 4 & 6 & 8 & 18 \\
F & 3 & 8 & 11 & 72 \\
G & 3 & 20 & 47 & 179 \\
H & 5 & 11 & 20 & 47 \\
I & 2 & 6 & 7 & 25 \\
\hline
\end{tabular}

(Source: MSIC, 2006, p.5)

Subsequently, the study resorted to overlay and map the 13-sector creative industries based on the DCMS classification to the MSIC 2008. Although MSIC 2008 does not have specific classifications for creative industries in Malaysia, many of its detailed levels allow some forms of matching and identification with those of the established 13-sector creative industries. This feature may allow users to add more dimensions in future documentation and measurement work.

The process of mapping and matching the creative industries as identified in the DCMS taxonomy to the Malaysian context (via the MSIC document) was tedious at best. Meticulous effort was required to extract the coding of creative activities under MSIC that best reflect and coincide with those specified under DCMS. In this pioneering attempt, the exercise began with extracting data from existing classifications and then systematically reorganising them to separately account for the 13 sectors of creative industries as identified by the DCMS taxonomy. Generally speaking, the attributes of the creative industries are somewhat more difficult to identify and more tedious to measure than traditional industries, thus, requiring a certain degree of caution (CIE, 2009).

Nonetheless, the tedious process of searching and sieving through the items in the current MSIC 2008 and then match them to the UK's 13 sectors have yielded some positive outputs. This endeavour allowed us to gauge the extent of convergence or divergence in terms of matching the creative industries of both countries. Based on a simplistic and arbitrary assessment, indeed, the MSIC 2008 has items that match with the UK's 13-sector. Thus, the identified items from Malaysia's MSIC 2008 that coincide with the UK's classification can then be considered and classified as part of Malaysia's creative industry. The results of the matching process are illustrated in Table 7 below. 
Khoo Suet Leng, Nurwati Badarulzaman, Narimah Samat, Morshidi Sirat \& Sharifah Rohayah Sheikh Dawood Creative Cities Research In Penang, Malaysia: A Review Of Conceptual And Methodological Framework

Table 7: Matching Malaysia's MSIC 2008 to UK's SIC

\begin{tabular}{|c|c|c|c|}
\hline \multicolumn{3}{|c|}{$\begin{array}{c}\text { UNITED KINGDOM'S CREATIVE INDUSTRIES } \\
\text { ACCORDING TO THE 2007 STANDARD INDUSTRIAL } \\
\text { CLASSIFICATION (SIC) FOR ANNUAL BUSINESS } \\
\text { SURVEY (ABS) DATA }\end{array}$} & $\begin{array}{l}\text { MALAYSIA'S CREATIVE INDUSTRIES } \\
\text { IDENTIFIED FROM THE MALAYSIA } \\
\text { STANDARD INDUSTRIAL } \\
\text { CLASSIFICATION (MSIC) 2008 VER. 1.0 }\end{array}$ \\
\hline \multirow{2}{*}{$\begin{array}{l}\text { Mappin } \\
\text { g } \\
\text { Docume } \\
\text { nt } \\
\text { Chapter }\end{array}$} & \multirow[t]{2}{*}{ Sectors } & $\begin{array}{l}\text { STANDARD INDUSTRIAL } \\
\text { CLASSIFICATION (SIC) } \\
\text { (UNITED KINGDOM) }\end{array}$ & $\begin{array}{l}\text { MALAYSIA STANDARD INDUSTRIAL } \\
\text { CLASSIFICATION (MSIC) } 2008 \\
\text { (MALAYSIA) }\end{array}$ \\
\hline & & Description & $\begin{array}{l}\text { Description } \\
\end{array}$ \\
\hline \multirow[t]{2}{*}{1} & \multirow[t]{2}{*}{ Advertising } & Advertising agencies & \multirow[t]{2}{*}{ Item 73100 - Advertising } \\
\hline & & Media representation & \\
\hline \multirow[t]{2}{*}{2} & \multirow[t]{2}{*}{ Architecture } & Architectural activities & \multirow[t]{2}{*}{ Item 71101 - Architectural services } \\
\hline & & Specialised design activities & \\
\hline \multirow[t]{2}{*}{3} & \multirow[t]{2}{*}{$\begin{array}{l}\text { Art \& } \\
\text { Antiques }\end{array}$} & $\begin{array}{l}\text { Retail sale in commercial art } \\
\text { galleries }\end{array}$ & \multirow[t]{2}{*}{$\begin{array}{l}\text { Unable to identify a closest match to its UK } \\
\text { counterpart. }\end{array}$} \\
\hline & & $\begin{array}{l}\text { Retail sale of antiques including } \\
\text { antique books, in stores }\end{array}$ & \\
\hline 4 & Crafts & $\begin{array}{l}\text { Majority of businesses too small to } \\
\text { be picked up in business surveys. }\end{array}$ & $\begin{array}{l}\text { Unable to identify a closest match to its } U K \\
\text { counterpart. }\end{array}$ \\
\hline 5 & Design & Specialised design activities & Item 74109 - Specialized design activities n.e.c. \\
\hline \multirow[t]{2}{*}{6} & \multirow{2}{*}{$\begin{array}{l}\text { Designer } \\
\text { Fashion }\end{array}$} & Clothing Manufacture & \multirow{2}{*}{$\begin{array}{l}\text { Unable to identify a closest match to its UK } \\
\text { counterpart. }\end{array}$} \\
\hline & & Specialised design activities & \\
\hline \multirow[t]{6}{*}{7} & \multirow{6}{*}{$\begin{array}{l}\text { Video, Film } \\
\& \\
\text { Photography }\end{array}$} & Reproduction of video recording & \multirow{6}{*}{$\begin{array}{l}\text { Item } 47731 \text { - Retail sale of photographic and } \\
\text { precision equipment } \\
\text { Item } 59110 \text { - Motion picture, video and television } \\
\text { programme production activities } \\
\text { Item } 59120 \text { - Motion picture, video and television } \\
\text { programme post-production activities } \\
\text { Item } 59130 \text { - Motion picture, video and television } \\
\text { programme distribution activities } \\
\text { Item } 59140 \text { - Motion picture projection activities } \\
\text { Item } 74200 \text { - Photographic activities }\end{array}$} \\
\hline & & Photographic activities & \\
\hline & & $\begin{array}{llll}\begin{array}{l}\text { Motion picture } \\
\text { production activities }\end{array} & \text { and video } \\
\end{array}$ & \\
\hline & & $\begin{array}{l}\text { Motion picture, video \& TV post- } \\
\text { production activities }\end{array}$ & \\
\hline & & $\begin{array}{ll}\text { Motion picture and video } \\
\text { distribution activities }\end{array}$ & \\
\hline & & Motion picture projection activities & \\
\hline \multirow[t]{7}{*}{$9 \& 10$} & \multirow{7}{*}{$\begin{array}{l}\text { Music, } \\
\text { Visual \& } \\
\text { Performing } \\
\text { Arts }\end{array}$} & $\begin{array}{lll}\begin{array}{l}\text { Sound recording } \\
\text { publishing activities }\end{array} & \text { and music } \\
\end{array}$ & \multirow{7}{*}{$\begin{array}{l}\text { Item } 18200 \text { - Reproduction of recorded media } \\
\text { Item } 59200 \text { - Sound recording and music publishing } \\
\text { activities } \\
\text { Item } 85421 \text { - Music and dancing school } \\
\text { Item } 90001 \text { - Theatrical producer, singer group band } \\
\text { and orchestra entertainment services } \\
\text { Item } 90002 \text { - Operation of concert and theatre halls } \\
\text { and other arts facilities } \\
\text { Item } 90007 \text { - Activities of producers or } \\
\text { entrepreneurs of arts live events, with or without } \\
\text { facilities } \\
\text { Item } 90009 \text { - Creative, arts and entertainment } \\
\text { activities n.e.c. }\end{array}$} \\
\hline & & Reproduction of sound recording & \\
\hline & & Performing arts & \\
\hline & & Support activities to performing arts & \\
\hline & & Artistic creation & \\
\hline & & Operation of arts facilities & \\
\hline & & $\begin{array}{l}\text { Motion picture, television and other } \\
\text { theatrical casting }\end{array}$ & \\
\hline \multirow[t]{5}{*}{11} & \multirow[t]{5}{*}{ Publishing } & Book publishing & \multirow{5}{*}{$\begin{array}{l}\text { Item } 58110 \text { - Publishing of books, brochures and } \\
\text { other publications } \\
\text { Item } 58130 \text { - Publishing of newspapers, journals, } \\
\text { magazines and periodicals in print or electronic } \\
\text { form } \\
\text { Item } 58190 \text { - Publishing of catalogues, photos, } \\
\text { engraving and postcards, greeting cards, forms, } \\
\text { posters, reproduction of works of art, advertising } \\
\text { material and other printer matter n.e.c. } \\
\text { Item } 82191 \text { - Document preparation, editing and/or } \\
\text { proofreading } \\
\text { Item } 82192 \text { - Typing, word processing or desktop } \\
\text { publishing }\end{array}$} \\
\hline & & Publishing of newspapers & \\
\hline & & $\begin{array}{llll}\begin{array}{l}\text { Publishing } \\
\text { periodicals }\end{array} & \text { of journals and } \\
\end{array}$ & \\
\hline & & Other publishing activities & \\
\hline & & News agency activities & \\
\hline \multirow[t]{4}{*}{$8 \& 12$} & \multirow{4}{*}{$\begin{array}{l}\text { Software \& } \\
\text { Electronic } \\
\text { Publishing }\end{array}$} & Reproduction of computer media & \multirow{4}{*}{$\begin{array}{l}\text { Unable to identify a closest match to its UK } \\
\text { counterpart. }\end{array}$} \\
\hline & & $\begin{array}{l}\text { Business and domestic software } \\
\text { development }\end{array}$ & \\
\hline & & Computer consultancy activities & \\
\hline & & Other software publishing & \\
\hline $8 \& 12$ & & Publishing of computer games & Item 62010 - Computer programming activities \\
\hline
\end{tabular}


PLANNING MALAYSIA

Journal of the Malaysia Institute of Planners (2015)

\begin{tabular}{|c|c|c|c|}
\hline & $\begin{array}{l}\text { Digital \& } \\
\text { Entertainment } \\
\text { Media }\end{array}$ & $\begin{array}{l}\text { Ready-made interactive leisure and } \\
\text { entertainment } \\
\text { development }\end{array}$ & \\
\hline \multirow[t]{5}{*}{13} & \multirow[t]{5}{*}{ Radio \& TV } & Radio broadcasting & \multirow{5}{*}{$\begin{array}{l}\text { Item } 60100-\text { Radio broadcasting } \\
\text { Item } 60200-\text { Television programming and } \\
\text { broadcasting activities }\end{array}$} \\
\hline & & $\begin{array}{l}\text { Television programming } \\
\text { broadcasting activities }\end{array}$ & \\
\hline & & $\begin{array}{l}\text { TV programmes production } \\
\text { activities }\end{array}$ & \\
\hline & & $\begin{array}{l}\text { Motion picture, video \& TV post- } \\
\text { production activities }\end{array}$ & \\
\hline & & $\begin{array}{l}\text { TV programme distribution } \\
\text { activities }\end{array}$ & \\
\hline
\end{tabular}

Although the current MSIC 2008 system cannot be regarded as the ultimate source for measuring Malaysia's creative industries, the MSIC 2008 does provide a basis or a platform for accounting and analysing the creative industries in Malaysia. The process of overlaying and matching the DCMS taxonomy with the MSIC 2008 was faced with many challenges given the inconsistencies and differences in economic activity categories adopted by these two documents. The following section discloses key methodological challenges and constraints encountered during the course of sourcing and collecting data on economic dimensions for Malaysia's creative industries.

\section{METHODOLOGICAL CHALLENGES}

\section{Conventional methods (i.e. three-sector) still in use}

Almost all of Malaysia's Economic Reports and Five-Year Malaysia Plans adopted the conventional standard classifications based on the three traditional sectors as identified in the Clark-Fisher's 3-Sector Model, namely, agriculture, manufacturing and services. However, creative industries which are predominantly service-based industries do not feature sufficiently under the umbrella of 'services industries' as shown in most recent Malaysian government blueprints. It is indeed a challenge to identify and extract data related to creative industries from these reports based on the DCMS classification.

\section{Multiple and ever-evolving definition of creative industries}

As elucidated in the Australian case, 'convergence' due to technological change and advancement is rapidly transforming definitions of industries and occupations (CIE, 2009). So much so that forces of economic globalisation such as technological innovation have invariably reorganised the way people work (Brown \& Lauder, 2001). Specifically, digitisation and the 'almost universal access' to low cost telecommunication platform by the Internet has reorganised the nature of work by people, organisations and industries (CIE, 2009). Due to the pervasiveness of advanced technology, industries that were once separated such as broadcasting, telecommunications and information technologies are now 
Khoo Suet Leng, Nurwati Badarulzaman, Narimah Samat, Morshidi Sirat \& Sharifah Rohayah Sheikh Dawood Creative Cities Research In Penang, Malaysia: A Review Of Conceptual And Methodological Framework

converged and overlapped. This situation resulted in changing work orientations involving a wide array of different types of businesses, occupations and skills. Oftentimes, these businesses, occupations and skills are not (yet) documented and listed as publishable statistical data for public consumption (Costa, 2008).

\begin{abstract}
Absence of data from government agencies
Since research on creative industries is relatively new in the Malaysian scene, the Malaysian Department of Statistics does not (as yet) have up-to-date and publishable statistics and census data based on the creative industries taxonomy adopted in this study. There is a lack of panel or time series data on creative industries in Malaysia, or, for the individual states in Malaysia. This situation has posed another challenge in terms of comparing and contrasting the contribution of creative industries to other states in Malaysia, and to the wider national economy.
\end{abstract}

\title{
Inability to calculate Location Quotient
}

The absence of vital quantitative data such as 'total contribution of creative industries to GDP' and 'total number of employees in creative industries' further hampers efforts to tabulate the 'location quotient' for this study. Literature on creative industries and creative cities shows that the 'location quotient' is a useful indicator to show the spatial distribution and density analysis of the creative industries in a particular location, which is a prerequisite and determinant to brand a place as a creative city (Evans, 2009; Lazzeretti, Boix \& Capone, 2009; Trullén $\&$ Boix, 2008). By definition, location quotient refers to the percentage of city employment relative to the percentage of national employment in the creative sectors $(1=$ national average) (Evans, 2009). In this study, the location quotient cannot be tabulated due to the lack of critical data. At this stage, the study is unable to identify which locality qualifies to brand itself as a creative epicenter in order to enhance its competitiveness and strategic positioning in Malaysia and globally.

\section{Issues of data reconciliation}

The process of charting the economics dimensions of Malaysia's creative industries becomes more challenging when faced with data inconsistency and discrepancy such as references to different (raw) sources, reference to different time periods as well as issues on definitions, semantics and epistemology as mentioned earlier. Similar issues and challenges were encountered in Australian studies (CIE, 2009). Arguably, Malaysians working in creative industries can be elusive and 'hidden' in statistical terms. For instance, a Malaysian architecture professor who is classified under the higher education industry should also be accounted as part of the creative industries (i.e. architecture). Interestingly, the Australian scenario also reported that some creative industries have a high 
percentage of volunteers and employees who are unpaid. Issues of data inconsistency and discrepancy make it more difficult to capture the actual contribution of the creative industries to the broader national economy.

\section{Creative workers who hold more than one occupation}

The flexibility of work in the creative industry enables some creative workers to hold more than one occupation at any given time (CIE, 2009). Research in Australia reveals that $63 \%$ of Australian artists are holding more than one job (Throsby \& Hollister, 2003 cited in CIE, 2009). Malaysia has no empirical evidence as yet to support this statement; however, it is not surprising if some Malaysian creative workers also hold multiple jobs just like their Australian counterparts. Should this be the situation, it would pose another challenge in terms of documenting the actual employee headcount as well as tabulating the gross value added of creative industries to the overall Malaysian economy.

\section{The Creative Trident approach - a compounded challenge?}

Insofar most studies have viewed the creative economy from either the industry or the occupational perspective (DCMS, 2010; AuthentiCity, 2008; Toh, Choo \& Ho, 2003). To reconcile the different orientations and to strengthen the creative economy analysis, a new approach to mapping the creative economy has been proposed. The creative trident approach identified by the ARC Centre of Excellence for Creative Industries and Innovation (CCI) is a 'nexus between industry and occupation classification' (CIE, 2009) which aims to provide a holistic and accurate estimate of the creative workforce. The creative trident approach proposes a cross-classification of employment by industry and occupation that permits the involvement and inclusion of three broad classes of employees, namely, i) specialist creatives; ii) support workers; and iii) embedded creatives as illustrated in Table 8. By definition, 'specialist creatives' are workers employed in creative occupations in creative industries; whilst 'support workers' are workers employed in creative industries but in non-creative occupations. The third category of 'embedded creatives' refers to workers hired in creative occupations, but in industries that do not produce creative products and services (CIE, 2009).

Table 8: The creative trident approach

\begin{tabular}{llcl}
\hline Category of Employees & $\begin{array}{c}\text { Employment with } \\
\text { Creative Industries }\end{array}$ & $\begin{array}{c}\text { Employment within } \\
\text { other Industries }\end{array}$ & Total Employment \\
\hline $\begin{array}{l}\text { Employment in creative } \\
\text { occupations }\end{array}$ & Specialist creatives & Embedded creatives & $\begin{array}{l}\text { Total employment in } \\
\text { creative occupations }\end{array}$ \\
$\begin{array}{l}\text { Employment in other } \\
\text { occupations }\end{array}$ & Support workers & & $\begin{array}{l}\text { Total creative } \\
\text { wotal }\end{array}$ \\
$\begin{array}{l}\text { Total employment in } \\
\text { creative industries }\end{array}$ & & \\
\hline
\end{tabular}

(Source: CIE 2009: 20) 
Khoo Suet Leng, Nurwati Badarulzaman, Narimah Samat, Morshidi Sirat \& Sharifah Rohayah Sheikh Dawood Creative Cities Research In Penang, Malaysia: A Review Of Conceptual And Methodological Framework

Although the creative trident approach displays a wider and holistic view of the entire creative economy, the approach is not without its limitations. Firstly, since the trident approach is an employment-based measurement, there are no good and valid measures of output by occupation. As such, it is impossible to estimate the contribution by embedded creatives to the output of the industries that employed them. Secondly, the employment estimates in the creative trident approach are not comparable to conventional industries since this approach mixes the concepts of industries and occupations. Using a creative trident approach across industries may result in double counting at best (CIE, 2009).

\section{CONCLUDING REMARKS}

As contemporary literature and reality would affirm, many developed and developing nations as well as cities around the world are now gearing up to become creative cities, where the creative industries of these cities play a pivotal role towards economic development. Research on creative cities is perceived as most timely to chart the roadmap, milestones and key economic dimensions to illustrate the emergence of a creative economy as the new engine of growth. Malaysia is at this critical phase of national development trajectory where postindustrial sectors such as services and the creative industries are earmarked as the impetus for growth and progress. Malaysia is poised to capitalise on the dynamism of major cities such as Kuala Lumpur, Penang and Johor Bahru to spur economic development. The synergy between creativity and cities has inherently pointed to the importance and emergence of creative cities in Malaysia and ways to transform Malaysian cities to become a creative city in their own right.

As Malaysia's economy shifts towards services and the creative industries, it is hoped that the findings derived from this paper would generate more discussions on creative industries, creative cities and creative economy; and subsequently spur strategic initiatives and local interests to bring research in this area to greater heights. 


\section{ACKNOWLEDGEMENT}

The authors acknowledge the support of Universiti Sains Malaysia's Research University Grant (1001/PSOSIAL/816189) for this project.

\section{REFERENCES}

AuthentiCity (2008, February). Creative City Planning Framework. A Supporting Document to the Agenda for Prosperity: Prospectus for a Great City. Prepared for the City of Toronto by AuthentiCity. Toronto. Canada. 1-44.

Brown, P. \& Lauder, H. (2001). Capitalism and social progress. The future of society in a global economy. Hampshire: Palgrave.

Centre for International Economics (CIE) (2009, June 30). Creative Industries Economic Analysis. Final Report. Prepared for Enterprise Connect and the Creative Industries Innovation Centre (CIIC). Canberra: Centre for International Economics.

Cooke, P. \& Lazzeretti, L. (2008) (Eds). Creative Cities, Cultural Clusters and Local Economic Development. Cheltenham: Edward Elgar.

Costa, P. (2008). Creativity, Innovation and Territorial Agglomeration in Cultural Activities: The Roots of the Creative City. In Creative Cities, Cultural Clusters and Local Economic Development, Cooke P. \& Lazzeretti L., eds. Cheltenham: Edward Elgar. 183 - 210.

Department for Culture, Media and Sport (DCMS) (2010). Creative Industries Economic Estimates (Experimental Statistics), Full Statistical Release, 9 December 2010. Retrieved August $\quad 9, \quad 2011$ from http://www.culture.gov.uk/images/research/CIEE_Full_Release_Dec2010.pdf

Evans, G. (2009). Creative Cities, Creative Spaces and Urban Policy. Urban Studies, 46 (5\&6), 1003-1040.

Florida, R. (2002). The Rise of the Creative Class: And How It's Transforming Work, Leisure, Community and Everyday Life. New York: Basic Books.

Florida, R. (2004). Cities and the Creative Class. New York: Routledge.

Florida, R. (2006, October). The Nation in Number. Where the Brains Are. Location unknown: The Atlantic Monthly.

Florida, R. (2008). Who's Your City? How The Creative Economy Is Making Where To Live The Most Important Decision of Your Life. New York: Basic Books.

Hing, A.Y. (2008). Evolving Singapore: the creative city. In Creative Cities, Cultural Clusters and Local Economic Development, Cooke P. and Lazzeretti L., eds. Cheltenham: Edward Elgar. 313 - 337.

Jacobs, J. (1972). Economy of Cities. England: Penguin Books Limited.

Kern, P. \& Runge, J. (non-dated). KEA briefing: towards a European creativity index. Place unknown: Publisher unknown. 191-205.

Kharas, H., Zeufack, A. \& Majeed, H. (2010). Cities, People \& the Economy. A Study on Positioning Penang. A collaborative research between Khazanah Nasional and The World Bank.

Khoo, S.L. \& Nurwati, B. (2011). Planning George Town as a Creative City: A Conceptual Framework. Proceedings of the 5th International Conference on Built Environment in Developing Countries - Rehumanizing the Built Environment. 6-7 December 2011, Penang. 1191-1207. 
Khoo Suet Leng, Nurwati Badarulzaman, Narimah Samat, Morshidi Sirat \& Sharifah Rohayah Sheikh Dawood Creative Cities Research In Penang, Malaysia: A Review Of Conceptual And Methodological Framework

Landry, C. (2000). The Creative City: A Toolkit for Urban Innovators. Strout: Comedia. Lazzeretti, L., Boix, R. \& Capone, F. (2009). Why do creative industries cluster? An analysis of the determinants of clustering of creative industries. IERMB Working Paper in Economics, $\mathrm{n}^{\circ}$ 09.02, April 2009, accessed date 1 April 2012.

Lee, D. (2011). "Creative Cities: Lessons for Penang” by Charles Landry. A talk presented by Charles Landry. Retrieved June 29, 2011 from Source:http://www.seri.com.my/v3/index.php?option=com_content\&view=arti cle\&id=182:qcreative-cities-lessons-for-penangq-by-charleslandry\&catid=38:latestnews \&Itemid $=54$

Liverpool City Council (2009, November). Liverpool's Creative Industries. Understanding the impact of Liverpool European Capital of Culture 2008 on the city region's creative industries. Impacts 08 based on research undertaken by Burns Collett \& Merseyside ACME, and Peter Campbell. Liverpool. United Kingdom. $1-74$.

Lorenzen, M. \& Frederiksen, L. (2008). Why do cultural industries cluster? Localization, urbanization, products and projects. In Creative Cities, Cultural Clusters and Local Economic Development, Cooke P. \& Lazzeretti L., eds. Cheltenham: Edward Elgar. 155 - 179.

Malaysia Standard Industrial Classification (MSIC) (2008). Malaysia Standard Industrial Classification 2008, Version 1. Kuala Lumpur: Percetakan Nasional Berhad.

Montgomery, J. (2005). Beware 'the Creative Class'. Creativity and Wealth Creation Revisited. Local Economy, 20 (4), 337-343.

Sasaki, M. (2008, March). Developing Creative Cities through Networking. Place unknown: Publisher unknown.

Smith, R. \& Warfield, K. (2008). The creative city: a matter of values. In Creative Cities, Cultural Clusters and Local Economic Development, Cooke P. \& Lazzeretti L., eds. Cheltenham: Edward Elgar. 287 - 312.

Toh, M.H., Choo, A., \& Ho, T. (2003). Economic Contributions of Singapore's Creative Industries. In Economic Survey of Singapore First Quarter 2003, with inputs from Economics Division Ministry of Trade and Industry and Creative Industries Strategy Group Ministry of Information, Communications and the Arts. Retrieved August 9, 2011 from http://portal.unesco.org/culture/en/files/29669/11370847883MICA__Economic_Contribution_Singapore_2003.pdf/MICA\%2B$\%$ 2BEconomic\%2BContribution\%2BSingapore\%2B2003.pdf

Trullén, J. \& Boix, R. (2008). Knowledge externalities and networks of cities in the creative metropolis. In Creative Cities, Cultural Clusters and Local Economic Development, Cooke P. \& Lazzeretti L., eds. Cheltenham: Edward Elgar. 211 236. 